2. Celia Moore, Hugh Gunz, and Douglas T. Hall, "Tracing the Historical Roots Of Career Theory in Management and Organization Studies," in Handbook of Career Studies, ed. Hugh Gunz and Maury Peiperl (Thousand Oaks: Sage Publications, 2007), 18.

3. Max Weber, Economy and Society, ed. and trans. by Guenther Roth and Claus Wittich (1921; Los Angeles: University of California Press, 1968), 958.

4. As Weber states in his chapter on "Bureaucracy" in Economy and Society, the bureaucratic official is "set for a 'career' within [a] hierarchical order. . . . He expects to move from the lower, less important and less well paid, to the higher position. The average official naturally desires a mechanical fixing of the conditions of promotion" (963).

5. Pierre Bourdieu, Homo Academicus, trans. Peter Collier (Stanford: Stanford University Press, 1988), 217.

6. Donald Hall, Careers In and Out of Organizations (Thousand Oaks: Sage Publications, 2002), 6.

\title{
Caribbean
}

\section{TIM WATSON}

ATHOUGH I'm not sure Raymond Williams would approve, this A Victorian keyword essay begins with a twenty-first-century keyword search. Using the University of Miami's Project Muse subscription, a search for "Caribbean" in the journal Victorian Studies since 2000 yields 46 items, of which only ten are full-length articles. Perhaps unsurprisingly for a field that embeds a British monarch in its name, keyword searches in Victorian Studies for British geographical locations result in far more hits: 243 for Edinburgh, 293 for Manchester, and 1,462 for London. By this measure, the Caribbean is about as important as Brighton (40) and Newcastle (47). When Victorian Studies focuses on imperial and international topics, India (389), America (348), Ireland (291), and Australia (208) count as much more important than the Caribbean. Comparisons to journals in American literary and cultural studies are instructive: Early American Literature (159 results for "Caribbean" since 2000) and Early American Studies (112 results since 2003) are far more Caribbean-focused. Most 
strikingly, $J 19$ (which unlike the two early American journals covers the whole of the nineteenth century) has published as many full-length articles (ten) with a Caribbean focus in its four years of existence as Victorian Studies has in the last seventeen years. The unavoidable inference is that the Caribbean remains marginal to Victorian studies, even as the Caribbean region is growing in importance in nineteenth-century American studies.

One explanation for the dearth of Victorian scholarship on the Caribbean is that the field simply reflects the neglect of the Caribbean in Britain after the end of slavery in the 1830s. After the upheavals and intense debates over the slave trade and slavery in the forty years before Victoria came to the throne, the Caribbean did slip from public consciousness in Britain, while India rose in imperial and economic importance. But if the region and its people were discussed less in Parliament and in London and provincial newspapers, the continuing cultural importance of the Caribbean is registered by its role in works by major writers of the Victorian period: Jane Eyre and Vanity Fair most obviously, but also in such novels as Treasure Island and Armadale. Periodically, the Caribbean snapped back to the center of Victorian culture, most prominently in the divisive debate over Governor Edward Eyre's suppression of the Morant Bay rebellion in Jamaica in 1865. More far-reachingly, Catherine Hall and other historians involved in the influential Legacies of British Slave-Ownership project have been arguing that the political, economic, and cultural benefits that accrued to many Britons from trade and capital accumulation in the West Indies profoundly shaped nineteenth-century Britain long after the official emancipation of all enslaved people in $1838 .^{1}$ The fact that Victorians stopped talking about the Caribbean did not mean that the region ceased to be significant; indeed, the reluctance to talk about the region may have signaled a discomfort on the part of many Britons in disclosing the source of their economic, political, and cultural power. Victorianists therefore should be focusing on the Caribbean much more than we currently do.

Victorianists should also be spending more time discussing works in nineteenth-century Caribbean studies. As Caroline Levine points out, in spite of "the wealth of transnational scholarship that has emerged in Victorian literary studies ... it is surprising that so much of the field remains organized around British authors." ${ }^{2}$ Faith Smith's study of the late nineteenth-century Trinidadian author John Jacob Thomas, Creole Recitations (2002), generated a roundtable in the premier journal of Caribbean studies, Small Axe, but was not reviewed in either Victorian Studies or Victorian Literature and Culture, despite Thomas's being best 
known for Froudacity, his caustic response to Victorian man of letters James Anthony Froude. ${ }^{3}$ Evelyn O'Callaghan's Women Writing the West Indies, 1804-1939 (2004) and Raphael Dalleo's Caribbean Literature and the Public Sphere (2011) have likewise had significant impacts in Caribbean studies while going unreviewed in leading Victorian studies journals. ${ }^{4}$ These works, with their emphasis on creolization, racial formation, imperial identities, and multilingual literary connections, would add significantly to Victorian studies, which remains too focused on Britain.

There is still a pressing need, in other words, to decolonize Victorian studies, even though many of the major works in Anglophone postcolonial literary studies have focused on the nineteenth century, such as Gauri Viswanathan's Masks of Conquest and Outside the Fold, Ian Baucom's Specters of the Atlantic, and of course Edward Said's Culture and Imperialism. ${ }^{5}$ Perhaps we see signs of a nascent Caribbean turn in the field in the vibrant and positive response to Nathan Hensley's Forms of Empire (2016), which devotes significant attention to the Morant Bay uprising and the Caribbean more broadly. ${ }^{6}$ Christopher Taylor's forthcoming Empire of Neglect: The West Indies in the Wake of British Liberalism (2018) may signal a more wholehearted turn toward the Caribbean. ${ }^{7}$ Maybe scholars looking to the Caribbean will notice how few places in the region are named for Queen Victoria, in contrast to other former British colonies. Meanwhile, turning back to Britain, recent news suggests growing awareness of the historical interdependence of British and Caribbean places and people, throughout the nineteenth century and beyond, in line with Hall's legacies of slave-ownership project. University of Liverpool students living in a residence hall named for one of Victorian Britain's leading politicians have launched a petition to rename Gladstone Hall, on the grounds that the source of William Gladstone's family's fortune in the slave trade and in Caribbean sugar plantations ought to disqualify him from the honor of presiding symbolically over an institution of higher learning. ${ }^{8}$ It remains to be seen whether Britain — not to mention the scholarly field of Victorian studies-is ready for the kind of reckoning with empire, slavery, and the Caribbean that would come with such a rethinking.

\section{Notes}

1. Catherine Hall, et al., Legacies of British Slave-Ownership: Colonial Slavery and the Formation of Victorian Britain (Cambridge: Cambridge University Press, 2016). See also Legacies of British Slave-Ownership, http://www.ucl.ac.uk/lbs/. 
2. Caroline Levine, "From Nation to Network," Victorian Studies 55, no. 4 (2013): 647-66, 647.

3. Faith Smith, Creole Recitations: John Jacob Thomas and Colonial Formation in the Late Nineteenth-Century Caribbean (Charlottesville: University of Virginia Press, 2002). Faith Smith's book was reviewed/discussed by Leah Rosenberg, Rhonda Cobham, Ifeoma Kiddoe Nwankwo, with a response by Smith. See "Book Discussion: Faith Smith, Creole Recitations," Small Axe 15, no. 2 (2011): 164-208.

4. Evelyn O'Callaghan, Women Writing the West Indies, 1804-1939: "A Hot Place, Belonging to Us" (London: Routledge, 2004); Raphael P. Dalleo, Caribbean Literature and the Public Sphere: From the Plantation to the Postcolonial (Charlottesville: University of Virginia Press, 2011).

5. Gauri Viswanathan, Masks of Conquest: Literary Study and British Rule in India (New York: Columbia University Press, 1989); Gauri Viswanathan, Outside the Fold: Conversion, Modermity, and Belief (Princeton: Princeton University Press, 1998); Ian Baucom, Specters of the Atlantic: Finance Capital, Slavery, and the Philosophy of History (Durham: Duke University Press, 2005); Edward W. Said, Culture and Imperialism (New York: Knopf, 1993).

6. Nathan K. Hensley, Forms of Empire: The Poetics of Victorian Sovereignty (Oxford: Oxford University Press, 2016); see also Tim Watson, Caribbean Culture and British Fiction in the Atlantic World, 1780-1870 (Cambridge: Cambridge University Press, 2008), 104-86.

7. Christopher Taylor, Empire of Neglect: The West Indies in the Wake of British Liberalism (Durham: Duke University Press, 2018).

8. Tinaye Mapako, “Gladstone's Legacy Is Murky: My University Shouldn't Glorify It," in The Guardian, November 24, 2017, https:// www.theguardian.com/education/2017/nov/24/gladstones-legacy-ismurky-my-university-shouldnt-glorify-it.

\section{Causality}

TINA YOUNG CHOI AND EDWARD JONES-IMHOTEP

T $\mathrm{N}$ the days following the 1865 derailment at Staplehurst, The Times offered an unsparing analysis of the factors leading to the accident: 